\title{
THE CONCEPT OF EQUITY AND AN EMPIRICAL RESEARCH ON THE PERCEPTION OF TURKISH JUDGES ABOUT JUDICIAL INTERPRETATION AND EQUITY
}

Hakkaniyet Kavramı ve Hakimlerin Hukuki Yorum ve Hakkaniyete Illişkin Algıları Üzerine Bir Emprik Araştırma

\section{Eylem ÜMIT ATILGAN*}

\begin{abstract}
This paper is a theoretical evaluation of the data obtained from a field research with the in-depth interviews of 80 judges and public prosecutors in Turkey. I attempted to understand what judges understand by the concept of equity and the way they carry it into practice when delivering a verdict. This article is actually the introductory headlines from the data I obtained at the first stage of a long and comprehensive study. What establishes the framework of the study is the question of "how judges make decisions". Since I designed the research in accordance with a qualitative method, it is dedicated to the purpose of understanding rather than surveying and assessment. This article serves as an introduction to a comprehensive study. In the subsequent stages of the study, considerably rich data obtained from in-depth interviews will possibly give way to a multidimensional analysis in various interpretational contexts and in the light of detailed codes. However, it would not be wrong to argue that judging the case from the available picture is open to the impact of value judgments. So I suppose, saying

* Yrd. Doç. Dr., Ankara Üniversitesi Hukuk Fakültesi Hukuk Felsefesi ve Sosyolojisi Anabilim Dalı Öğretim Üyesi
\end{abstract}


famous motto "wise judges are better than good codes" (Gute Richter sind noch wichtiger als gute Gesetze,") will not be impetuosity.

Keywords: Philosophy and Sociology of Law, Equity, Judicial Interpretation, Legal Culture, Empirical Studies in Law

\section{ÖZET}

Bu metin hâkim ve savcılarla yapılmış saha çalışmasından elde edilen verilerin kuram 1şığında değerlendirilmesinden oluşmaktadır. Saha çalışmasında, Türk Yargı sisteminde en kıdemli hâkimler olan 1. sınıf hâkim ve savcılarla yaptığım derin mülakatlarla hâkimlerin hakkaniyet kavramından ne anladıklarını ve hüküm verirken özellikle takdir yetkisini kullanırken nasıl uyguladıklarını anlamaya çalışıı. $\mathrm{Bu}$ makalede sunacağım bilgiler aslında geniş kapsamlı ve uzun soluklu bir çalışmanın ilk ayağında elde ettiğim verilerden genel başlıklar olup alışmanın nihai çerçevesini "hâkimler nasıl karar verir" sorusu çizmekte. Bu sorunun yanıtını aramak için şimdiye kadar 80 kadar hâkimle derin mülakat yaptım. Araştırmayı nitel yönteme göre tasarladığım için bu çalışmanın amacının "tarama-ölçme" değil "anlama"ya yöneldiğini önemle vurgulamalıyım. Hâkimlerin hak ve nisfetle karar vermesi ilkesinin yarg1 sosyolojisi bakımından bir incelemesi olan bu makalenin "Gute Richter sind noch wichtiger als gute Gesetze" (İyi hâkimler, iyi yasalardan daha önemlidir) ${ }^{* *}$ mottosu ile başlaması bu nedenle anlaml.

Anahtar Sözcükler: Hukuk Felsefesi ve Sosyolojisi, Hakkaniyet, Hukuki Yorum, Hukuk Kültürü, Hukukta Emprik Araştırma

\section{INTRODUCTION}

This paper is a theoretical evaluation of the data obtained from in-depth interviews of judges and public prosecutors. During the in-depth interviews I held with the senior judges in the Turkish judiciary system, as well as with public prosecutors, I attempted to understand what judges mean by the concept of equity and the way they apply it when delivering a verdict. In this

\footnotetext{
** K. S. Bader, DRiZ, 1961, S. 237, available at http://www.ruhr-unibochum.de/rsozlog/daten/pdf/Roehl\%20-\%20Fehler\%20in\%20Gerichsurteilen.pdf on 03.06.2015
} 
respect, the study is an attempt at the field of activity which Dworkin refers to "as answering the question of what law is from the judge's perspective." Perspective of judges is usually defined as the basic component for internal legal culture. ${ }^{2}$ Since Friedman's definition of internal legal culture refers to the attitudes and behaviors of legal professionals, the research question of this survey can be considered as mean to understand the internal legal culture in Turkey. According to Volkmar Gessner's demonstration of framework to the legal culture research, courts are one of the institutional actors and they build up the field three which is called comparative implementation research. Following Professor Gessner's framework of legal culture, it can be said that, this study concerns with a components of legal cultures by focusing on the judges perceptions. ${ }^{3}$

The information I will present here is actually the broad conclusions from the data I obtained at the first stage of a long and comprehensive study. What establishes the framework of the study is the question of "how judges make decisions." In seeking an answer to this question, I have so far conducted in-depth interviews with about 80 judges and prosecutors. ${ }^{4}$ At the

1 Michael S. Moore, Legal Principles Revisited, Iowa L. Review, V. 82, 1997, p. 867-891.

2 Lawrence M. FRIEDMAN, The Legal System: A Social Science Perspective, New York: Sage, 1975, s. 193-194, 223-224.

3 Volkmar Gessner, "On the Methodology of Comparing Legal Phenomena" in Volkmar Gessner, Armin Hoeland, Csaba Varga (eds.) European Legal Cultures, UK: Dartmouth, 1996, p. 245. Gessner describes four field as follows: Field 1: Legaltheoretical and legal dogmatic comparison: Legal norms; Field 2: Legal comparison: Supreme court decisions/science of law; Field 3: Comparative implementation research: Institutional actors: courts, administration; Field 4: Comparison of legal systems/legal culture; Non-institutional actors: lawyers, citizens, business enterprises.

4 This part of the field research is conducted between 2009- 2011. Second part (the high court interviews) is continuing. The questionnaire of the semi structured depth-interviews is as follows:

Q1st What are the resources which you apply most, regarding your profession? Among those resources, what is the place of the case law (the decisions of the court of appeals) and how often the case law is applied? What can you say about the role of case law in judicial process considering your observations on your colleagues?

Q2nd In your view, how should the statement "the code shall be applied on the subjects where it refers literally and substantially" be interpreted?

Q3rd(To judges of civil courts) Do you encounter the legal gaps too often? What is the way that should be followed by judges when a legal gap is met in the proceedings?

Q4thWhat are the instruments which are used by the judges applying the judicial discretion? What instruments should be used by the judges applying the judicial discretion? Q5thWhat are the borders of the judicial discretion? What should they be?

Q6thHow should a judge act in cases where he does not find the norms that must be applied appropriate? 
next stage, I plan to hold interviews at the high courts. Since I designed the research in accordance with a qualitative method, its purpose is to understand rather than survey and assess. Thus, quality is the priority in the data, as opposed to quantity in a quantitative study. I should also note that the data I have so far obtained is more than 90 hours. The information I will offer here consists of a preliminary analysis of the data and the basic conclusions I obtained. It goes without saying that the new contexts to be drawn from the second analysis will enrich and deepen these conclusions. ${ }^{5}$

\section{II.THE CONCEPT OF EQUITY}

As a preliminary remark, I have to stress that the concept of equity is never univocal in Turkish jurisprudence. Actually, equity (aequitas-equitébilligkeit) is a term which has also different meanings in comparative law. In the English legal tradition, the term technically means a part of English

Q7thPlease mark the expressions which you find appropriate below

- Personal conditions should be considered in proceedings.

- The environment where the event which caused the trial occurred should be considered in the proceedings.

- Both personal and environmental conditions should be considered in the proceedings.

- Personal and environmental conditions should be ignored and the law should be applied to everyone objectively.

Q8thWhat is the role of the equity in the judicial process?

Q9thWhat does equitable judgment mean in your point of view?

Q10th (To judges of criminal courts) In your view, what is the role of discretional extenuation governed under Article 62 of Turkish Penal Code (which is also called "extenuation of necktie" in public speech in Turkey) in judicial activity? How is it applied in practice and how should it be applied? (What is your opinion about orientation, social conditions and to be damaged because of the crime?)

Q11th What is your opinion on the results relating the personal conviction of the judges in legislating techniques? How do you define personal conviction? (Article 138 (1) of Turkish Constitution: "Judges shall be independent in the discharge of their duties; they shall give judgment in accordance with the Constitution, law, and their personal conviction conforming with the law")

Q12th (To judges of Criminal Courts) (Article 217 of Criminal Procedure Code: Estimation of Evidence- Judge may rely on only the evidences which were brought and discussed in the hearings. Those evidences shall be estimated by personal conviction of the judge without constraint.)

5 As it can be seen by the large diversity of questions and the number of the interview, the data obtained from this comprehensive field research has wide and very rich contexts. Some contexts such as judicial discretion or sources of law and enactment would be another articles issue. Some of the data which are obtained from this field research is already analysed under the title "The Principle of Equity in Turkish Law: A Judicial Sociology Research", in Legislation and Judicial Decision Making, (Norm Koyma-Hüküm Verme) Ankara: Ankara Üniversitesi Basımevi, 2011, p. 317-340. 
law originally administrated by the Lord Chancellor and later by the Court of Chancery as distinct from that administrated by the courts of common law. These courts were later to be called the "courts of equity." 6 Law of equity was developed separately from the body of law as laid down by the common law courts from about the 15 th century. ${ }^{7}$ The rules, maxims and practice of equity were shaped during the equity jurisdiction. ${ }^{8}$

On the other hand, although the continental codes (like the French, German, Swiss civil codes) contain many references to equity, this concept is not defined in any of these codes. ${ }^{9}$ But it is obvious that in the continental judicial tradition, equity plays a significant role in adapting the written law to the rapidly changing society through the concepts of interpretation and the judges' powers of discretion. As it is always said by continental jurists: "Summum jus summa injura" ("The rigor of the law is the height of oppression") -- here there is no doubt that equity leaves the code vague for judicial interpretation and judicial interpretation allows the law to evolve with society. ${ }^{10}$

True, the origin of the common law and civil law systems' concepts of equity are only roughly the same. ${ }^{11}$ True English equity, developed from the intersection of Greek, Roman and Christian traditions, represented the perfect and powerful incarnation of the paradigm of political theology. In fact, in spite of the etymology, the concept of equity (English equity) is a translation of the Greek idea of epieikeia much more than of the Latin aequitas, so the set of associations of different, linguistic and conceptual elements reintroduces the issue of the roots of Western tradition when it ends up as equity in English. ${ }^{12}$

6 Also Called Courts of Conscience.

7 Harold Greville Hanbury, Modern Equity, The Principles of Equity, (7th edition), London: Stevens and Sons Limited, 1957, 1-9; G.W. Keeton, An Introduction to Equity, London: Sir Isaac Pitman \& Sons, 1938, p. 1-39.

8 Keeton, p. 104-107.

9 Peter De Cruz, Comparative Law in a Changing World, (2nd edition), London: Routledge Cavendish, 1999, p. 216.

${ }^{10}$ To point out this mission of judges, they are called "living codes" by some legal scholars. Faruk Erem, Psychology of Justice, (Adalet Psikolojsi) (8th edition), Ankara: Sevinç Matbaas1, 1988, p. 321.

${ }^{11}$ Charles S. Brice, Roman Aequitas and English Equity, Georgetown Law Journal, V.2, 1913-1914, p. 16-24.

${ }^{12}$ Cristina Constantini, Equity Different Talks, Social Science Research Network, Working Paper Series, 2008, SSRN Electronic Journal 12/2008; DOI:10.2139/ssrn.1315999, 
There is no doubt that the concept of equity in the Continental law tradition is more directly related to the Roman aequitas than the English equity.

The word aequitas, the equivalent of the English term "equity" in Roman law, was defined as "related to justice but distinguished from the positive law (ius)" in dictionaries of Roman law. ${ }^{13}$ Indeed, an examination into its historical use demonstrates that ius and aequitas have often been so closely related that they have become inseparable. ${ }^{14}$

The concept was used at times as opposite to "the written law (ius)" and served a corrective function for the current law. Looking back to definitions again, one of these defines the term as "one of the main principles which guide or are supposed to guide the development of law," while another one states that "it is one of the corrective and creative elements in the development of law." Aequitas is observed either in interpreting the written law or filling the gaps in a statute. In this context, it should be also noted that many jurists of Roman law underline the relationship between natural law and equity.

As a matter of fact, it can be seen that prominent jurists endorsing and celebrating the rejection of the Roman-scholastic notion of law during the period when equity was introduced into modern laws as a principle, that is, when Article 1 of the Swiss Civil Code was discussed and embraced. While the meaning of this first article was under discussion, a phrase which was included in the draft of the French Civil Law and was referred to by the jurists of the time is important in that it articulates the relationship between equity and natural law: "there exists an unchanging and universal law as the source of positive laws (lois positives), which is nothing but the natural reason governing men." 15

available at http://www.researchgate.net/profile/Cristina_Costantini2/publications on 03.06.2015, p. 3-6; Alastair Hudson, Equity \&Trust, London: Routledge, 2003, p. 8.

${ }^{13}$ Adolf Berger, Encyclopedic Dictionary of Roman Law, Philadelphia: American Philosophical Society, 1953, p. 354.

${ }^{14}$ Kadir Gürten, Aequitas in Roman Law, (Roma Hukukunda Hakkaniyet) Ankara: Adalet Yayınevi, 2008, 34.

${ }^{15}$ Claude du Pasquier, New Ideas in Appliance of the Law and the Court Decisions (Hukukun Tatbiki Hakkında Yeni Görüşler ve İsviçre Mahkeme İçtihatları) AÜHF Dergisi, translated by Jale Akipek, V.11, No. 3-4, 1954, p. 310-311. 


\section{THE CONCEPT OF EQUITY AND JUDICIAL DISCRETION IN TURKISH LAW}

Turkey adopted the Swiss Civil Code, which clearly charges judges with the task of deciding and exercising their powers of discretion in accordance with equity. ${ }^{16}$ Concerning the motives behind this choice in the Swiss Civil Code, which underlined the role of judges in the sources and implementation of law, Professor Eugen Huber, the writer of the preliminary draft, stated in his report as follows:

"We do not believe it would be advantageous if the legislature deprived the courts of all discretion in recognizing this point. The interpretation may vary, during the existence of the statute, in accordance with the opportunities of the text and the state of public conscience, and it would be a mistake to draw a statute in such a way as to make it impossible for the courts to follow the development of public opinion without a change of the text .... When the legislator intends to make a provision absolutely mandatory, he should say so. Where he fails to say so, the question will be decided in accordance with the spirit of the times." ${ }^{17}$

Apart from the Preliminary Provisions of the Turkish Civil Code, which were legislated in the same manner as the Swiss Civil Code, the legislator makes references to the concept of equity in various codes, including phrases such as "equitable compensation," "shall decide in accordance with equity." Furthermore, we should note that the concept of "conscientious conviction," a term closely related to equity, and the principle of rendering a verdict in

\footnotetext{
${ }^{16}$ Relevant articles in the Turkish Civil Codes are as follows:

"A. Sources and Enactment of Law

Art 1

The written law is applicable to all matters to which either the letter or spirit of any of its provisions refer. In the absence of a provision of such law applicable to a case, the judge shall decide according to customary law and in the absence of custom, according to the rule which he would establish were he acting as legislator. He shall base his decisions upon the solutions adopted by doctrine (writers) and in judicial decisions."

III. Judicial Power of Discretion

Art 4

The judge shall decide in accordance with law and equity in matters where the law grants the power of discretion or prescribes the consideration of the needs of a situation or justified reasons.

${ }^{17}$ Francois Geny, The Legislative Technique of Modern Civil Codes, in Science of Legal Method Select Essays, Modern Legal Philosophy, V. 9, Chapter XII, sec.13, ed.: Ernest Bruncken, Boston: The Boston book Company, 1917.
} 
accordance with conscientious conviction are both constitutional guarantees. ${ }^{18}$ As a matter of fact, an examination of the codes reveals that equity is among the general standards of law. The concepts such as "a reasonable period of time," "critical reasons," "special conditions," "the offender's past and social relations", "the offender's behaviors after committing a crime and during the judicial process" or "consequences of the penalty for the future of the offender," involves equity. In order to consider the role of the principle of equity in judicial activity from a broader perspective, we will take a brief look into the judicial procedures currently in force in Turkey.

During the beginning of a particular case, i.e. the first stage of the judicial activity, the judge is supposed to obtain as clear a picture as possible of the case before him/her. In answering the questions of whether the incident really took place, and where, how and when it took place if it did, the judge uses an inductive method.

This stage is actually a sort of assessment activity where the judge authenticates the case. At this stage, the judge is not in the world of law, but rather identifies the case by means of the inductive method and using the impression and information s/he obtains through the five senses in the physical and psychological world (such as finding during the investigation that the food stuff is rotten), the rules of experience (such as the impossibility, under normal conditions, of recalling with all its details an event which happened a long time ago) and technical information (such as referring to a forensic expert for the time of the crime of murder).

The long-dated books I read for this stage used the title "hakim" meaning "eminently prudent and erudite in all matters, philosopher," which

\footnotetext{
${ }^{18}$ The article of the constitution is as follows

Art 138

Independence of the Courts

Judges shall be independent in the discharge of their duties; they shall give judgments in accordance with the Constitution, law, and their personal conviction (conscience) conforming with the law. No organ, authority, office or individual may give orders or instructions to courts or judges relating to the exercise of judicial power, send them circulars, or make recommendations or suggestions.

No questions shall be asked, debates held, or statements made in the Legislative Assembly relating to the exercise of judicial power concerning a case under trial. Legislative and executive organs and the administration shall comply with court decisions; these organs and the administration shall neither alter them in any respect, nor delay their execution.
} 
is one of the definitions of the judge in the Mecelle [the Compendium- The Ottoman Civil Code]. A judge makes assessment and arrives at a decision both at this first stage and the second stage, which consists of legal denomination, i.e. finding the legal norm appropriate for a particular event and situation, and is also called legal description, denomination, argumentation or legal rhetoric. Given that assessment of evidence takes place at this stage, we can once more conclude that the obligation for the judge to decide in accordance with law and equity applies to this stage as well.

Indeed, the role of equity should not be confined to Article 4 of the Turkish Civil Code, because treating equity without detaching it from justice (which should actually be the case) makes it a superior principle of the system.

Doctrinally, the principles are listed according to their varying meanings on the basis of the contexts in which they are used, and there is reference to five categories of principles:

1. A principle which refers to a general norm: It refers to a principle of a general nature in terms of its scope, such as the norm which is applicable to contracts of every kind.

2. A principle which refers to a norm constructed using ambiguous terms: Here, there is the use of ambiguous and ambivalent concepts and terms, such as the abuse of a right or goodwill.

3. A principle which refers to a norm describing a legal system, one of its elements and the paramount values of one of its institutions, such as the principle of justice as the most supreme value and the principle of equity in terms of its relationship to justice.

4. A principle which refers to a norm stipulating an obligation in order to achieve a certain policy or an end, such as ensuring the protection of customers by the authorities through effective measures.

5. A principle pertaining to the bodies exercising law, such as the principle specifying the method of selecting the norm to be applied, or systematizing the law. ${ }^{19}$

${ }^{19}$ Gülriz Uygur, Law, Ethics and Principles, (Hukuk, Etik ve İlkeler), Ankara: Siyasal Kitapevi, 2006, p. 13-14. 
So, what does equity encompass as a principle?

In his magnum opus The Rhetoric, Aristotle establishes the following relationship between equity, mercy and a person's story, intention, and personal situation:

"Equity bids us be merciful to the weakness of human nature; to think less about the laws than about the man who framed them, and less about what he said than about what he meant; not to consider the actions of the accused so much as his intentions, nor this or that detail so much as the whole story; to ask not what a man is now but what he has always or usually been. It bids us remember benefits rather than injuries, and benefits received rather than benefits conferred; to be patient when we are wronged; to settle a dispute by negotiation and not by force; to prefer arbitration to motion-for an arbitrator goes by the equity of a case, a judge by the strict law, and arbitration was invented with the express purpose of securing full power for equity. The above may be taken as a sufficient account of the nature of equity." 20

In another work titled Nicomachean Ethics, Aristotle underlines the role of equity in applying justice as a more abstract and general principle to a particular case.

"What creates the problem is that the equitable is just, but not the legally just but a correction of legal justice. The reason is that all law is universal but about some things it is not possible to make a universal statement which shall be correct. In those cases, then, in which it is necessary to speak universally, but not possible to do so correctly, the law takes the usual case, though it is not ignorant of the possibility of error. And it is none the less correct, for the error is in the law nor in the legislator but in the nature of the thing, since the matter of practical affairs is of this kind from the start. When the law speaks universally, then, and a case arises on it which is not covered by the universal statement, then it is right, where the legislator fails us and has erred by oversimplicity, to correct the omission-to say what the legislator himself would have said had he been present, and would have put into his law if he had known. Hence the equitable is just, and

${ }^{20}$ Aristoteles, Rhetoric, (350 BC) trans.: Mehmet H. Doğan, İstanbul: Yapı Kredi Yayınları, 1995, p. 84-85. 
better than one kind of justice-not better than absolute justice but better than the error that arises from the absoluteness of the statement. And this is the nature of the equitable, a correction of law where it is defective owing to its universality. In fact this is the reason why all things are not determined by law, that about some things it is impossible to lay down a law, so that a decree is needed. For when the thing is indefinite the rule also is indefinite. ${ }^{21}$

As is clear from the quotes by Aristotle, equity and justice are intertwined. When filling the gaps and considering the changing conditions, equity greatly contributes to justice, whereas in stipulating uneven procedures for uneven conditions, it once more and indirectly ensures the administration of justice although, at first glance, it appears to violate equality. ${ }^{22}$

The similar and different terms corresponding to equity in Roman Law could be listed as follows: "justice in a particular case," "equitable/conscientious," "correction of the notion of justice emanating from the law," "same treatment for the same event," or "acting in accordance with equality, expediency."23

Besides Aristotle, the works of Cicero constitute another important source on the uses of equity. Transposing to a great extent Aristotle's thoughts into Roman Law, Cicero makes a crucial comment on equity: "The greatest justice can be the greatest injustice; that is, the stricter is the application of a legal rule to a particular case, the more unjust, or inequitable, are its consequences. Summum ius summa iniuira."24

Almost all texts about equity define the two basic interrelated functions of the concept: the function of equity pertaining to justice serves to arrive at a fair conclusion by administering justice, an abstract and general principle, to a particular case. The term "justice in a particular case" is referred to as corresponding to this very function. In all decisions the judge makes by

${ }^{21}$ Aristotle, Nicomachean Ethics, (BC 350) Trans.: by W. D. Ross, London: Oxford University Press, 1994, p. 14.

${ }^{22}$ Gürten, p. 32.; Edward Roelker, The Meaning of Aequitas, Aequus and Aeque In the Code of Canon, in: The Jurist, V.6, 1946, p. 239-274.

${ }^{23}$ Gürten, p. 48 .

${ }^{24}$ Gürten, p. 59. 
considering the requirements of a particular case, there is a reference to the judge's obligation to make an equitable decision in this respect. ${ }^{25}$

Hegel set out the following definition of equity underlying the function of "the justice in particular case":

"Equity involves a departure from formal rights owing to moral or other considerations and is concerned primarily with the content of law suit. A court of equity, however, comes to mean a court which decides in a single case without insisting formalities of a legal process or in particular, on the objective evidence which the letter of the law may require. Further, it decides on the merits of the single case as a unique one, not with a view to disposing of it in such a way to create a binding legal precedent or future." 26

On the other hand, the second function is closely related to the first and refers to the relaxation of the law so as to prevent possible injustices brought by the strict application of the law. Historical process demonstrates that British Equity Courts contribute to the development of the law of equity by performing this function. It is obvious that this second function of equity relates to its corrective and constructive role in the development of law, as stated by Aristotle and Cicero. As noted in the recognized definitions of equity, which I quoted at the beginning of this paper, the decisive role of equity in the development of law is considered either in interpreting the current law or filling the gaps in a statute.

\section{THE PERCEPTIONS OF EQUITY OF TURKISH JUDGES}

In this conceptual framework where I confined myself rather to a brief glance into remarks on the meaning and the role of the concept equity, I also would like to focus on the functions of equity in intertwined areas. The corrective and creative role of equity in the development of law, which we referred to as its second function, manifests itself in the fields of interpretation and filling gaps. To begin with the question of interpretation, by stipulating in Article 1 of the Turkish Civil Code that "The written law is applicable to all matters to which either the letter or spirit of any of its

${ }^{25}$ Court of Appeals (Yargitay) clearly defines equity as "justice in particular case" in several decisions. For instance 9. H.D. 1968, E.691,K. 4629; 2.H.D. E. 2006/12234, K.2006/18458, T. 27.12.2006; 2. H.D. E. 2007/539, K. 2007/16529, T. 27.11.2007.

${ }^{26}$ G.W.F. Hegel, Philosophy of Right, (1821), translated by T.M. Knox, London: Oxford University Press, 1952, paragraph 223. 
provisions refer." Article 1 refers to the activity of applying abstract rules to concrete cases through methods of interpretation such as literal, teleological, historical and systematic interpretation. Leaving outside the scope of the present text the data on how Turkish judges resort to which interpretation method and what the most frequently used method is, I would like to emphasize the general approach of the judges towards interpretation. With its function of justice in a particular case, interpretation is of particular importance for the principle of equity.

Let us briefly examine of the perception of interpretation of judges involved in two different approaches: Literal and teleological interpretive approaches. In the literal interpretive approach, the interpreter asks himself/herself the following question: How should I interpret the written rule before me in order to comply with the will of its legislator? In the teleological approach, the interpreter, on the contrary, deals with how the law should be administered and shaped in order to achieve the aims of meeting the needs of social life awaiting satisfaction and restoring the disturbed balances which need to be reestablished.

In their responses to the question about interpretation, the term I most frequently heard from our judges was the "Court of Appeals" . Most judges, so to speak, changed the question posed by an interpreter in the literal interpretation to "How should I interpret the rule before me so that I comply with the will of the Court of Appeals?" The dominant role of the Court of Appeals come into prominence regarding the face-to-face, open court and direct judicial hearings which are essential to understand what the "justice in particular case" is. I would like to quote some brief examples from the interviews. As the original words of judges and public prosecutors, they are very striking:

Judge: “(...) so what does the Court of Appeals want?” It is far beyond the spirit and letter of the law; first of all, I think that judges are definitely and excessively constrained by the question about "What does the Court of Appeals think about it?"-which prevents them from thinking what is beyond."

Another interviewee used exactly the following phrase about the issue of interpretation:

Judge: "Administration is literal in our country." 
Ë̈: "What about the spirit of the law?"

Judge: "Of course you are bound by the Court of Appeals for it has the last word. We have to act as the Court of Appeals says. Otherwise, if we act in accordance with the spirit of the law, our spirits will be ruined."

What the interviewee refers to by saying "our spirits will be ruined" is the grading system required for promotion. ${ }^{27}$ Below is another interviewee's interpretation of the effect of grading and promotion system upon legal proceedings:

Judge: "We look at the jurisprudence to see how the Court of Appeals decided on a matter. Because the Court of Appeals is the authority to make the final judgment, and to reverse a judgment to send it back to us ... it might impede or adversely affect our promotion. Even if we resist, the case will be referred to the General Board of Criminal Department, whose opinions are based on certain jurisprudence; therefore, I am against the practice of grading in the Court of Appeals. Yet, it is our job anyway and completely automatic promotions are wrong. They could introduce a different promotion system so as to ensure greater attention. They could introduce another promotion system that particularly serves autonomy. Yet, the grading system really affects the conscientious convictions of judges."

The interviewees continued to comment on their experiences and observations on the issue:

Judge: "I have always observed that many judges do not seek to discover the truth, they rather 'seek to make irreversible decisions.' I have even seen some colleagues who first shaped the case in their minds before listening to the witnesses, and asked the questions accordingly."

E $\ddot{\mathbf{U}}$ : "So they resort to jurisprudence even in the case assessment stage, don't they?"

An interviewee evaluates the shadow of the Court of Appeals in interpretation with its very role in the doctrine:

\footnotetext{
${ }^{27}$ The consequences of the grading system of The Court of Appeal have been discussed by jurists for a long time in Turkey. Some judges name this system as "supreme court oligarchy”. See Kemal Şahin (Judge of Kazan), Division of Powers and The Judicial Independency in Turkey, (Türkiye'de Kuvvetler Ayrılığı ve Yargı Bağımsızlığı), in: HFSA, V. 16, 2007, p. 237.
} 
Judge: "I mean the laws are increasingly deprived of their spirit. Why? For we are jurists, but we, most of us, gave up on our powers to become technicians. Thus, the spirit is lost but in general we are good at literal interpretation, for there are others who show us how to. We have masters before us. We literally implement the laws but they have no spirit. Why? Because teleological interpretation is missing. Unless we make teleological interpretations, we only have an article of law before us, which we should use and apply in any conflict. We are content by simply saying 'we cannot act otherwise; this is the task of legislation.' If the law is wrong, legal arrangements will be made, legislation performs its duty and will abolish or amend the article, only after which I can change its administration. If you say so, then you will be interpreting the law literally. But you will never be making teleological interpretations; justice in particular case will never manifest itself; and you will never decide in accordance with equity. This is what I think."

I found that a minority of the judges who complained of the present situation recommended the teleological interpretation for the interpretive approach, which should be more often used in practice. Nevertheless, what is particularly underlined in the sociological approach to law for teleological interpretation is that judges should make use of, and be learned in, social sciences such as sociology, philosophy and psychology. My impression about the interviews is that the lack of information in these fields has been compensated for with a 'knowledge of life'. I regret to say that I very often observed subjective evaluations and prejudices about the regular course of life. The judges told me that they often made use of prejudices concerning ethnic, religious and sexual attributes as knowledge of life, and thus, they accordingly administered justice in particular case. These subjective evaluations and prejudices remind me "subconscious element in the judicial process" definition of Cardozo. He says "it is often through these subconscious forces that judges kept consistent with themselves and inconsistent with one another." ${ }^{28}$ Cardozo implies that it is not easy for a judge to be aware of subconscious forces:

"All their lives, which they do not recognize and cannot name, have been tugging at them - inherited instincts, traditional beliefs, acquired

${ }^{28}$ Benjamin Nathan Cardozo, The Nature of the Judicial Process, (1921) New Haven: Yale University Press, 2009, p. 12. 
convictions; and the resultant is an outlook on life, a conception of social needs (...)" 29

During the interviews I usually observed that some of judges name "knowledge of life" or "justice in particular case" to the subconscious elements and cover them. ${ }^{30}$ To offer a few examples from the interviews:

Judge: “A woman appears and says 'this man harassed me.' I look at them and see the husband is ugly but the other man is handsome. Then I conclude that the woman wanted to have an affair with this man, but then she yielded to social pressure and claimed that it was harassment to save face."

Prosecutor: "They brought the man before me for smuggling. The guy is from Kilis, ${ }^{31}$ he must have absolutely done it."

Judge: "We have become judges of character. When I look at a man's face, it is clear to me whether he is the perpetrator."

With my colleagues with whom I shared such examples, of which I have quoted only a few, we thought that this phenomenon reminded us of a qadi's activity. Actually as it is rightly said by Gadamer, "it is not so much our judgments as it is our prejudices that constitute our being." ${ }^{32} \mathrm{He}$ restores to its rightful place a positive concept of prejudice and implies prejudices are not necessarily unjustified and erroneous, so that they inevitably distort the truth. Prejudices are simply conditions whereby we experience something and they are biases of our openness to the world. ${ }^{33}$ The essential and vital issue about prejudices is not about "having or not having them", but hiding them. So taking off the curtains covering them is necessary to ascertain. Gadamer defines "knowing how to distinguish between blind prejudices and

\footnotetext{
${ }^{29}$ loc.cit.

${ }^{30}$ A former judge Professor Dinçkol states that, wrong judgments of the judges are mostly caused by prejudices. Especially performing profession for long time could engrave the prejudices. And those prejudices interfere in the judicial process unconsciously. Judge should be awake and a hard worker to avoid from this situation. Abdullah Dinçkol, Basic Principals of Judicial Judgment Process, HFSA, V. 2, 1995, p. 175.

${ }^{31}$ A border town

${ }^{32}$ Hans-Georg Gadamer, Philosophical Hermeneutics, 2nd Edition, (trans. \& ed.) David E. Linge, Berkeley: University of California Press, 2008, p. 9.

${ }^{33}$ loc. cit
} 
those which illuminate, between false prejudices and true prejudices" as the critical task of hermeneutics. ${ }^{34}$

In the light of these facts about the perception of judicial interpretation of the judges, let's look at the equity definitions which are derived from interviews:

Judge: "Now, equity; in my opinion, the equity of a criminal court judge and the one of a civil court judge differ from each other."

Prosecutor "The equity is the direct essence, the base of the criminal justice." That is, formal truth inflicts damage, we must look for equity in the criminal procedure, we must be equitable."

Judge: "For us, (a criminal court judge) equity, damage suffered by the injured party, the purpose of the perpetrator, the greed to commit a crime, all these are things of great significance. As we have just stated, "the surroundings where the crime was committed and besides that, the conditions. For us, the conditions refer to the motive, the degree of intent, criminal record, holding all these elements under the microscope. Because, as a criminal court judge, I must remedy the disturbed balance. This is my understanding of giving a verdict in line with the equity principle. The equity plays a role at the moment of discretion of the punishment."

I observed that the theory and implementation of the content of the equity principle was different from each other and most of the criminal court judges had this view. The "expertise report" was the dominant actor in the responses of the civil court judges. A judge criticized the role of the expert in a legal proceeding:

Judge: "In my opinion, both the equity principle and the authority of discretion arise from the "report given by an expert" in Civil Courts. I mean, the judges bind themselves within the expert's report and accordingly exercise their judicial discretion, so is my view."

A juvenile criminal judge stated that criminal court judges applied the principle of equity when they abstained from applying the norm:

\footnotetext{
${ }^{34}$ Hans-Georg Gadamer, The Problem of Historical Consciousness, in: Interpretive Social Science: A Reader, ed. Paul Rabinow, William Sullivan, California: University of California Press, 1979, p. 156.
} 
Judge: "There are cases where the equity principle is applied to save a child. You see that the crime has been committed when you technically examine the case, but you can feel sorrow and take pity for the child. There are in fact so many example cases in my mind, but I can't remember one now.

E.Ü.: That means, a crime exists, but you don't want to impose a penalty.

Judge: Yes, it's so. We didn't feel up to apply the law. I sometimes cross it in my mind, I mean, we, the judges, find sometimes a point to save somebody! The equity requires it."

I also heard from the interviewed juvenile prosecutors that they recorded down the acts of children that fell outside the act constituting the related crime as subject of complaint, as they put it, "in moderate statements" in statements.

Prosecutor: "For instance, the child says 'I was a little loaded at that point', but you turn a deaf ear; otherwise drug usage could come in question for that child."

Some judges view the equity principle as an alternative to the implementation of the codes; the following example shows it:

"Judge: Yes, it might be so. Then we try to find a way out where ever possible! I tell you explicitly; sometimes we can give a verdict that is not in line with laws."

The largest majority of the judges responded yes to the statement "local characteristics must be taken into account during a proceeding". There was only one judge among criminal court judges who objected to this statement. Moreover, a criminal court judge gave an example and spoke about a trial where he decriminalized an act defined as crime in the law based on the customs and traditions in the region he once worked. The trial he spoke about was a case of theft in a coal storage area. Taking off some fruits in one's pockets from an orchard wasn't deemed as theft in accordance with the traditions in the region. So, referring to it, he was of the opinion that it shouldn't be judged as theft when somebody took away coal from a coal yard as much as he can carry away, a contrary judgment would be against the 
principle of equity, so was his view. Like the greatest majority of the judges, he also defined the equity as a way applied when one wants to by-pass the laws.

Execution of a proceeding with respect to the local characteristics and defining it within the scope of the equity principle was a very common approach with regard to "oath". Even though the procedure of taking an oath is defined in the law, it was stated in the interviews that taking oath on "three stones" or objects believed to represent "zulfiqar" were common applications pursuant to traditions from one region to another.

Even though the general approach could be defined so, I observed so many definitions of equity, or, as the phrase goes, I experienced thereby an inflation of definitions:

A family court judge defined the equity as follows:

Judge: "Equity is very important. Namely, the verdict you give must be accepted by both of the parties."

Another civil court judge identified giving verdicts in line with equity with a restraint of enrichment:

Judge: "Giving a verdict in line with equity shouldn't enrich one of the parties while upsetting the other party, that must be basic rule."

A criminal court judge who will get retired soon summarized how the equity is understood in practice:

Judge: "Everyone has a different understanding of equity, because there is a differentiation concerning justice that's subjective for everybody. But I don't want to fatigue you now; you will understand it as you progress with interviews, it is ideological, class-specific etc."

There were also others who defined the equity as something that can be sensed with feeling and intuition:

Prosecutor: "I am someone who believes in justice. The equity resides in me. It can be different from one case to another, it has no fixed definition."

\section{CONSLUSION}

Since this study is first and foremost based on a qualitative field research, I should particularly avoid generalizations and jump into definitive 
conclusions. However, it would not be wrong to argue that judging the case from the available picture is open to the impact of value judgments. At this juncture, I believe the distinction between morality and ethics gains prominence. As is well known, morality is defined as the systems of value judgments concerning behaviors prevailing in a certain time and at a certain place. Such morality is different from ethics, thus it is called social morality. On the other hand, ethics has two meanings: the first of which refers to the principles that are directly or indirectly drawn from the knowledge of human's value. In its second meaning, ethics is a discipline of philosophy which presents or at least expected to present verifiable information in ethical issues concerning humans. ${ }^{35}$

The role of equity in filling the gaps in a statute and exercising the power of discretion is of particular importance. I concluded from the judges' responses that equity is most often understood or perceived as 'satisfied conviction.' A considerably large portion of the judges mentioned "eased conscience" and "satisfaction of the parties in a case." This is a conceptualization which points to the period before the stage in the evolution of the concept of conscientious conviction, when logic and reason were adopted as guides. ${ }^{36}$ Some of the judges stated that they made equitable decisions once they achieved impartiality. Yet, the interviewees most often mentioned equity with reference to the conditions of a particular case. Among these, only a few perceived the conditions of a particular case as the personal situation of the parties and their particular contexts. Another surprising observation was the considerably high rate of those who perceived and expressed these conditions as customary law, a significant part of whom were criminal court judges. Of my interviewees, a considerable number of criminal court judges stated that they considered in their decisions the conditions of a particular case, which also contained the rules of customary law; therefore they considered these rules when implementing the law, although they are not accepted as one of the sources in criminal procedure.

\footnotetext{
${ }^{35}$ Uygur, p. 2. Kuçuradi prefers the concept of "moral" instead of "social morality". For the division and differences of "moral-ethic", "value-value judgement": Ioanna Kuçuradi, Human and Values, (İnsan ve Değerleri), Ankara: Türkiye Felsefe Kurumu, 1998, p.12-13, 40-41, 106-109.

${ }^{36}$ Metin Feyzioğlu, Conscience (Personal Convict) in Penal Jurisdiction, (Ceza Muhakemesinde Vicdani Kanaat), Ankara: Yetkin, 2002, p. 21-38.
} 
At this juncture, it will not be wrong to say that a lot of interviewees' equity perceptions are shaped by pre-understandings which prevail against the conditions of particular case, ethic, the certain meaning of the written law and justice. In some examples which were told by the interviewees about the judicial decision making process, these pre-understandings become as final decision directly. They tell these cases as good experiences of equity judgment. ${ }^{37}$

Since Holmes said "the life of the law has not been logic: it has been experience." (...) what the courts declare to have always been the law is in fact new." "Phrases, "how judges think" is one of the most interesting questions of empirical legal studies. Although the claim of legal realists that gives the legislative role to the courts seems problematic with the democratic principles and legal certainty, ${ }^{39}$ it evokes the interest to the structural analysis of the judicial process. Describing the role of equity and the equity perceptions of judges in enactment as "a value jurisprudence does not exalt judges to a role that they do not have now, but rather recognizes their existing role for what it is."

As mentioned above, the subject of this paper is limited to the presentation of a preliminary analysis and the first codes on the data obtained from the field. Therefore, it serves as an introduction to a comprehensive study. In the subsequent stages of the study, considerably rich data obtained from in-depth interviews will possibly give way to a multidimensional analysis in various interpretational contexts and in the light of detailed codes.

\footnotetext{
${ }^{37}$ For an empirical legal study analyzing the pre-understandings as a resource of subjectivity in judicial process see Mithat Sancar, Eylem Ümit Atılgan, "Justice can be Bypassed Sometimes": Judges and Prosecutors in the Democratization Process, İstanbul: TESEV, 2009.

${ }^{38}$ Oliver Wendell Holmes, The Common Law, in: The Mind and Faith of Justice Holmes, His Speeches, Essays, Letters and Judicial Opinions, ed. Max Lerner, 1989, p. 51, 54.

${ }^{39}$ For an evaluation of legal realism and different approaches separate from the main stream see Ülker Gürkan, Legal Realism, (Hukuki Realizm) Ankara:Ankara Üniversitesi Basımevi, p. 225, 1967.

${ }^{40}$ For the concept of value jurisprudence see Joshua B. Shiffrin, A Practical Jurisprudence of Values: Re-Writing Lechmere, Inc. v. NLRB 186, in: Harvard Civil Rights-Civil Liberties Law Review, V. 41, 2006.
} 


\section{KAYNAKÇA}

Aristotle, (1995) Rhetoric, trans.: Mehmet H.Doğan, İstanbul: Yapı Kredi Yayınlar1.

Aristotle, (1994) Nicomachean Ethics, Translated by W. D. Ross, London: Oxford University Press.

Atılgan Ümit Eylem, (2011) "The Principle of Equity in Turkish Law: A Judicial Sociology Research", in Legislation and Judicial Decision Making, (Norm Koyma-Hüküm Verme) Ankara: Ankara Universitesi Basımevi.

Bader, K. S. (1961) DRIZ, available at http://www.ruhr-unibochum.de/rsozlog/daten/pdf/Roehl\%20-

$\% 20$ Fehler\%20in\%20Gerichsurteilen.pdf on 03.06.2015.

Berger, Adolf (1953) Encyclopedic Dictionary of Roman Law, Philadelphia: American Philosophical Society.

Brice, Charles (1913-1914) S. Roman Aequitas and English Equity, Georgetown Law Journal, V.2,

Cardozo, Benjamin Nathan (2009) The Nature of the Judicial Process, (originally published in 1921), New Haven: Yale University Press.

Constantini,Cristina (2008) Equity Different Talks, Social Science Research Network, Working Paper Series, SSRN Electronic Journal 12/2008;

DOI:10.2139/ssrn.1315999, available at http://www.researchgate.net/profile/Cristina_Costantini2/publications, on 03.06.2015.

Cruz, Peter De (1999) Comparative Law in a Changing World, 2nd edition, London: Routledge Cavendish.

Dinçkol, Abdullah (1995) Basic Principals of Judicial Judgment Process, (Karar Verme Süreci İçinde Hakimin Uyması Gereken Temel İlkeler) HFSA, V. 2.

Erem, Faruk (1988) Psychology of Justice, (Adalet Psikolojisi) 8th edition, Ankara: Sevinç Matbaası.

Feyzioğlu, Metin (2002) Conscience (Personal Convict) in Penal Jurisdiction, (Ceza Muhakemesinde Vicdani Kanaat), Ankara:Yetkin. 
Friedman, Lawrence M. (1975) The Legal System: A Social Science Perspective, New York: Sage.

Gadamer, Hans-Georg (2008) Philosophical Hermeneutics, 2nd Edition, (trans. \& ed.) David E. Linge, Berkeley: University of California Press.

Gadamer, Hans-Georg (1979) The Problem of Historical Consciousness, Interpretive Social Science: A Reader, ed. Paul Rabinow, William Sullivan, Berkeley: University of California Press.

Geny, Francois (1917) The Legislative Technique Of Modern Civil Codes, in Science Of Legal Method Select Essays, Modern Legal Philosophy, Vol 9, Chapter XII, sec.13, ed.: Ernest Bruncken, Boston: The Boston Book Company.

Gessner, Volkmar (1996) "On the Methodology of Comparing Legal Phenomena" in Volkmar Gessner, Armin Hoeland, Csaba Varga (eds.) European Legal Cultures, UK: Dartmouth.

Greville Hanbury, Harold (1957) Modern Equity, The Principles of Equity, 7th edition, London: Stevens and Sons Limited.

Gürkan, Ülker (1967) Legal Realism, (Hukuki Realizm) Ankara: Ankara Üniversitesi Basımevi.

Gürten, Kadir (2008) Aequitas In Roman Law (Roma Hukukunda Hakkaniyet), Ankara:A dalet Yayınevi.

Hegel, G.W.F. (1952) Philosophy of Right, 1821, translated by T.M. Knox, London: Oxford University Press.

Holmes, Oliver Wendell, (1989) The Common Law, The Mind and Faith of Justice Holmes, His Speeches, Essays, Letters and Judicial Opinions, ed. Max Lerner, NY:Transaction Publishers.

Hudson, Alastair (2003) Equity \&Trust, London: Routledge.

Keeton,G.W. (1938) An Introduction to Equity, London: Sir Isaac Pitman \& Sons.

Kuçuradi, Ioanna (1998) Human and Values, (İnsan ve Değerleri), Ankara:Türkiye Felsefe Kurumu.

re, Michael S. (1997) Legal Principles Revisited, Iowa L. Review, V. 82. 
Pasquier, Claude du (1954) New Ideas in Appliance of the Law and the Court Decisions, (Hukukun Tatbiki Hakkında Yeni Görüşler ve İsviçre Mahkeme İçtihatları) $A \ddot{U} H F$ Dergisi, translated by Jale Akipek, V.11, No. 3-4.

Roelker, Edward (1946) The Meaning of Aequitas, Aequus and Aeque In the Code of Canon, The Jurist, V.6.

Sancar, Mithat \& Eylem Ümit Atılgan, (2009) "Justice can be Bypassed Sometimes": Judges and Prosecutors in the Democratization Process, İstanbul: TESEV.

Shiffrin, Joshua B. (2006) A Practical Jurisprudence of Values: Re-Writing Lechmere, Inc. v. NLRB 186, Harvard Civil Rights-Civil Liberties Law Review, V. 41.

Şahin, Kemal (2007) (Judge of Kazan), Division of Powers and The Judicial Independency in Turkey, (Türkiye'de Kuvvetler Ayrıllğı ve Yargıç Bağımsızlığı) HFSA, V. 16.

Uygur, Gülriz (2006) Law, Ethics and Principles, (Hukuk, Etik ve İlkeler) Ankara: Siyasal Kitapevi. 